\title{
Smart Manufacturing Support to Product Platforms in Industrialized House Building
}

\author{
Djordje Popovic $^{1 *}$, Shamnath Thajudeen ${ }^{1}$, and Alexander Vestin ${ }^{1}$ \\ ${ }^{1}$ PhD candidate, Department of Industrial Product development, Production and Design, \\ Jönköping University \\ *Corresponding author's e-mail: djordje.popovic@ju.se
}

\begin{abstract}
Swedish house building companies currently face many challenges in terms of fluctuating market demand, need for flexible product offering, non-uniform governmental regulations, high costs, and long lead times. These challenges affect both internal and external efficiency of companies. Product platforms have been used for more than a decade in this industry to improve both internal and external efficiency. However, the industry is still criticized for its inefficient and costly process. Smart manufacturing has emerged as means to improve the efficiency of internal processes and the question is if and how smart manufacturing can complement and support product platforms in industrialized house building. The aim of this study is to explore the potential of smart manufacturing to complement and support product platforms in theory and practice in the context of industrialized house building. A literature review and a multiple case study were chosen to fulfill the study objective. In total fourteen semi-structured interviews were conducted in two timber house building companies. The data was analyzed within and across cases using four platform assets for categorization: components, processes, knowledge and relationships. The results show that the smart manufacturing technologies are in both theory and practice mainly supporting the process platform asset through developing vertical and horizontal IT systems integration, definition and digitalization of flexible building systems, and transferring explicit drafting and engineering knowledge into parametric modelling tools.
\end{abstract}

\section{KEYWORDS}

Industry 4.0; smart production; process platform; off-site manufacturing; timber frame.

\section{INTRODUCTION}

Fluctuating market demand, need for flexible product offering, non-uniform governmental regulations, high costs, long lead times and low productivity are causes to many challenges that Swedish house building companies currently face (Lessing et al. 2015). A common challenge for house-building companies is balancing between standardization and customization to achieve external efficiency (Jansson 2013). Product platforms are used for more than a decade in this industry to address this challenge (ibid.), however were initially developed in the 90s with the emergence of mass customization in the manufacturing industries e.g. automotive. Smart manufacturing is also a paradigm that emerged from the manufacturing industries, where new technologies, methods and approaches were developed to address similar set of challenges with internal efficiency seen currently in industrialized house building (IHB). Furthermore, smart 
manufacturing can be regarded as a support for product platforms in the manufacturing industries (Kang et al. 2016; Mittal et al. 2017). However, research related to smart manufacturing in IHB is currently only in its early stage (Monizza et al. 2018) and so far there is limited knowledge on how smart manufacturing can support product platforms in IHB. There are, however, authors that have defined what smart manufacturing is and which technologies are used in the broader context of construction industry (Dallasega et al. 2018; Oesterreich and Teuteberg 2016). This has been taken as a starting point for the analysis in this study. This knowledge gap is, therefore, addressed with the following aim: to explore the potential of smart manufacturing to complement and support product platforms in theory and practise in the context of industrialized house building.

\section{THEORETICAL BACKGROUND}

According to Robertson and Ulrich (1998) product platform can be defined as "The collection of assets [i.e., components, processes, knowledge, people and relationships] that are shared by a set of products". Product platform approach is the process of identifying and utilizing commonalities among a firm's offerings, target markets, and the processes for creating and delivering new offerings (Halman et al. 2003). Product platforms have been studied in house building as well. Bonev et al. (2015) took a holistic perspective on platform-based development and execution in the sector of industrialized construction to increase the understanding of how mass customization can be facilitated. Thuesen and Hvam (2011) show an industrial application of platform approach for efficient on-site construction. Lessing et al. (2015) introduced a platform consisting of, process, technical, knowledge and supplier platform in industrialized house building. However, this approach is more adapted to the construction industry working with concrete buildings (Lidelöw et al. 2015). The definition coined by Robertson and Ulrich (1998) was used for the analysis in this study. Components and corresponding manufacturing resources are main foundation and the interfaces between modules are central for project configurations (Thuesen and Hvam 2011). To produce customized products efficiently, knowledge about production processes are gathered and refined to form the process asset of a platform (ibid.). According to Styhre and Gluch (2010), the knowledge asset is a mechanism for bridging between the stocks and flows of knowledge in organizations by integrating know-how and experience in activities. Relationship asset concerns the relationships within a company and with other companies in the supply chain, where some actors are more closely coupled to the platform than others (Green et al. 2005).

The concepts of smart manufacturing and other synonyms like industry 4.0, smart production or smart factory have not gained much attention in the construction industry despite the possible benefits. The concepts with a special focus in the construction environment is still in its formative years (Monizza et al. 2018; Oesterreich and Teuteberg 2016; Woodhead et al. 2018). Although there is no definition for smart manufacturing in the construction industry, Oesterreich and Teuteberg (2016) came up with an industry specific definition for Industry 4.0 concept in the construction industry. It comprises of interdisciplinary technologies to enable the digitization, automation and integration of the construction process at all stages of the construction value chain. Central technologies are: building information modelling (BIM), parametric design techniques, cloud computing and internet of things. In some cases, Industry 4.0 is used as a synonym to describe the increasing use of ICT and other manufacturing technologies. However, building information Modelling (BIM) is considered as the central technology for the digitalization of the construction industry (Monizza et al. 2018; Oesterreich and Teuteberg 2016). The state of the art 
of these technologies are on different levels of maturity. On the one hand, several technologies have reached market maturity and thus are currently available, e.g. BIM, Parametric design techniques, modularization. On the other hand, a few technologies are still at the formative stage, as prototypes and applications are being developed for mainstream use, e.g. additive manufacturing, augmented and virtual reality (AR\&VR) (Oesterreich and Teuteberg 2016). The adoption of smart manufacturing technologies would have implication for the whole construction industry, the involved companies, the environment and for employees. Beside the economic benefits for improving productivity, internal efficiency, quality and collaboration, the adoption can help to enhance safety, sustainability and thus to improve the poor image of the construction industry in the long run (Dallasega et al. 2018; Monizza et al. 2018; Oesterreich and Teuteberg 2016).

\section{METHOD}

The findings presented in this paper are twofold: theoretical and empirical. Theoretical findings were based on a literature review (Rumsey 2008) that later served as an analytical framework for empirical data collected in a multiple case-study (Karlsson 2016). The starting point of the analysis was the theoretical background presented in the previous chapter. Smart manufacturing technologies in construction industry were categorized according to four product platform assets (step 1 in Figure 1). The categorization was further used to conduct a literature review in the context of IHB using smart manufacturing technologies as keywords (step 2 in Figure 1). The motivation for this approach was the presence of literature on the identified technologies in IHB context that did not refer to smart manufacturing technologies. The formulated analytical framework was used for the final step of the method, i.e. analysis of empirical data (Figure 1).

The multiple case study was conducted at two Swedish timber house builders where theoretical selection was applied for case company selection (Karlsson 2016). Interviews were used to collect data with open ended questions. To achieve a holistic perspective, the interviews were carried out with respondents from various positions in the companies (ibid.): product development, production development and design phase. An interview guide was developed prior to the interviews to attain information in line with the aim of this study (Yin 1994). A total of 14 interviews, eight in company A and six in company B were performed ranging from 1 - 3 hours, where all three authors participated. The interviews were recorded, transcribed, and analysed using the analytical framework. It is important to note that the respondents were not specifically asked to define and describe how each of four platform assets were used, rather this was inferred based on the answers the respondents gave. Furthermore, the respondents were asked to describe what smart manufacturing would be in their companies. Some inferences regarding smart manufacturing technologies were made as not all the interviewees were familiar with the concept of smart manufacturing.

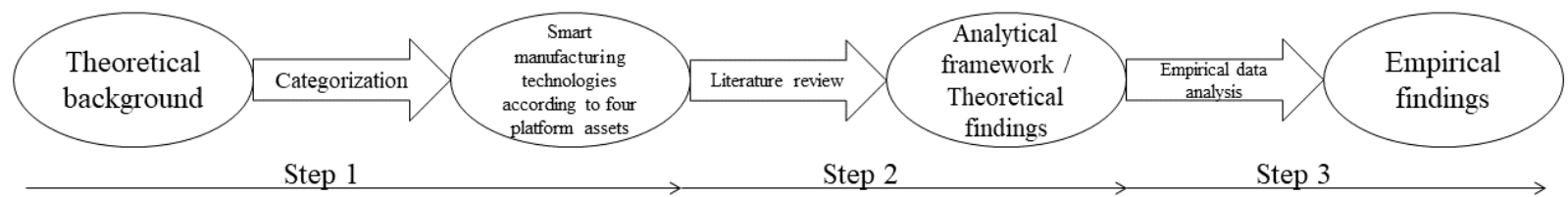

Figure 1. Data analysis 
MOC SUMMIT / MAY 2019

\section{FINDINGS AND ANALYSIS \\ Theoretical findings}

Said et al. (2017) presented an automated component generation model that relates to component asset of product platform. The model optimizes the trade-off between minimizing the total fabrication cost of the panels and minimizing the resulting design deviation from enforcing common platform designs for the panels. Within the process asset of product platform, Isaac et al. (2016) presented a methodology based on automated modularization from BIM data, and showed that a graph-based methodology can be useful to support the design of modular, adaptable buildings. Jensen et al. (2012) demonstrate parametric modelling in the process asset of product platform. The authors conclude that computer-aided design (CAD) tools used in the manufacturing industry can present new opportunities for design automation of building systems within the construction industry. Parametric modelling was also addressed by Khalili-Araghi and Kolarevic (2016) who uncover the potential for flexibility of parametric design and constraint definition within BIM software. Persson et al. (2009) address the process asset of product platform through vertical IT integration and claim that structuring information more effectively and applying a holistic information strategy at management level that incorporates use of information systems throughout the companies' organization, could considerably reduce the costs of information processing. Malmgren et al. (2011) investigated information integration and product modeling as a suitable technology to describe the product structure of modular houses. The information is transferred downstream from the customers view to the engineering, production and assembly views. The rules and constraints of the building system are transferred upstream from the assembly, production and engineering views to the customers view and hence define the customization limits of the product family. Theoretical findings are summarized in Table 1.

Table 1. Theoretical findings

\begin{tabular}{lcc}
\hline $\begin{array}{l}\text { Platform } \\
\text { assets }\end{array}$ & $\begin{array}{c}\text { Smart manufacturing in } \\
\text { construction (step 1) }\end{array}$ & $\begin{array}{c}\text { Product platform supported by smart } \\
\text { manufacturing IHB (step 2) }\end{array}$ \\
\hline Components & $\begin{array}{c}\text { Automation, robotics. } \\
\text { modularization/prefabrication } \\
\text { Processes }\end{array}$ & $\begin{array}{c}\text { Automated component generation } \\
\text { of Things, Vertical IT } \\
\text { integration, Parametric } \\
\text { modelling, AR\&VR }\end{array}$ \\
$\begin{array}{c}\text { Knowledge } \\
\text { Relationships }\end{array}$ & Horizontal IT integration & $\begin{array}{c}\text { Automated modularization based on BIM data, } \\
\text { Configuration systems }\end{array}$ \\
\hline
\end{tabular}

Eid Mohamed et al. (2017) presented configuration system in the process asset of product platform. The research demonstrates application of cutting-edge technologies in modes of integrating homebuyers in a participatory dialogue for a sustainable outcome. Singh et al. (2015) addressed the knowledge asset of product platform. The authors claim that the domain specific knowledge can be incorporated in BIM authoring tools by modelling rule-based BIM objects, parametrical constraints and visual programming tool. The integration of domain specific knowledge in modelling tools is helpful and reduces the efforts expended by the designer in production-oriented tasks. 


\section{Empirical findings}

The general description about the companies is given in Table 2. The description of current product platform assets and the existing support follows. Finally, the analysis of empirical findings of how smart manufacturing technologies can support the product platform assets is given in Table 3 .

Component platform asset. The building system is regarded as the foundation of component asset for both case companies. The dimensions of components, elements, and modules are predefined in terms of length, width, height, and thicknesses. For company B, building system solutions are developed based on manual operations with a low degree of automation in production.

Table 2 General description of case companies

\begin{tabular}{|c|c|c|}
\hline & Company A & Company B \\
\hline Business area & $\begin{array}{l}\text { Single family and multi-family } \\
\text { house builder with } 1000 \\
\text { employees }\end{array}$ & $\begin{array}{l}\text { Single family house builder with } 252 \\
\text { employees }\end{array}$ \\
\hline Building system & $\begin{array}{c}\text { Volumetric and panelized } \\
\text { elements with three brands for } \\
\text { standard \& customized products. }\end{array}$ & $\begin{array}{l}\text { Panelized elements with two brands for } \\
\text { standard \& customized products }\end{array}$ \\
\hline Customer & $\begin{array}{c}\text { Turnkey contracts and business } \\
\text { to business }\end{array}$ & Turnkey contracts \\
\hline Houses per year & 1500 including all brands & 500 houses including two brands. \\
\hline
\end{tabular}

Process platform asset. Both company A and B own the whole product realization process from the sales to the finished house on-site. The process is defined with clear gates, checkpoints, and planning backwards from: on-site assembly, manufacturing and design. Both companies have started realizing the advantages of parametric CAD modelling tools and had develop a custom library with predefined components to avoid rework in the detailed design. The aim of both companies is to optimize the product realization process so that information is only put into the system once. In both companies the use of parametric modelling tools has a positive implication on employee turnover through the reduction of training and education time for new employees.

Table 3. Smart manufacturing technologies support to the product platform assets

\begin{tabular}{lcc}
\hline Platform assets & Company A & Company B \\
\hline Components & $\begin{array}{c}\text { Flexible digital building system, } \\
\text { flexible manufacturing systems }\end{array}$ & $\begin{array}{c}\text { Flexible digital building system, flexible } \\
\text { manufacturing systems. }\end{array}$ \\
& with higher automation level. & \\
Processes & Sales configurator, vertical IT integration, parametric modelling, VR\&AR. \\
Knowledge & Digitalizing knowledge \\
Relationships & Horizontal IT integration \\
\hline
\end{tabular}

Knowledge platform asset. Both companies have digital database with documented descriptions regarding processes and products to support personnel. As the design phase is a bottleneck, the knowledge of utilizing the CAD software is transformed into parametric modelling tools. So far there is such application in CAD software for exterior walls for company B. 
Relationship platform asset. Both companies build long term relationships with the suppliers of materials and components, sub-contractors for on-site foundation and finishing work, and consultancy for engineering/drafting of installations. In company B, consultants working with electrical installations can add information directly into the CAD model thereby enabling horizontal integration in the supply chain. Internally, cross-functional teams are formed for the development and problem solving.

\section{DISCUSSION}

The empirical data shows that use of product platforms in organizations is currently more common than implementation of smart manufacturing technologies. However, companies have started to see the benefits of these technologies to increase the internal efficiency. Moreover, having a successful implementation of product platforms demands higher internal efficiency. Development of flexible and digitalized building systems are seen in both companies as means to achieve higher efficiency in generation of product variants for different product families. This is in line with the findings of Said et al. (2017). The necessity of the alignment between the manufacturing systems the building system, calls for the development of flexible manufacturing systems as well. Current challenge for company $\mathrm{A}$ is to develop the flexible building system, as it is constrained by the capabilities of a dedicated manufacturing systems, i.e. wall and floor assembly lines that were designed for a niche product, bought and implemented in 80's. Company B is not willing to invest in high level of automation as no production system suppliers yet have the solutions that match the flexibility of the building system.

Developing flexible sales configurators that enable configuration of not only the product assortment but also the floor layouts and geometries is in line with the development of flexible and digitalized building systems (Eid Mohamed et al. 2017). Both companies encounter challenges with the process efficiency due to sales accepting customer requirements that are outside the building system and assortment, which implies additional work in the design phase to fit the requirements as much as possible within the boundaries of the building systems and manufacturing systems. The challenge in both companies is that the existing configurators are not vertically integrated with their CAD and enterprise resource planning (ERP) systems. Moreover, ERP, CAD and other IT systems are currently not vertically integrated. This has negative impact on the efficiency of their internal processes as error-prone and tedious manual information transfer is needed, which is also in line with the findings of Persson et al. (2009) and Malmgren et al. (2011). Development of parametric modelling tools and digitalization of building systems are seen as ways to address the three main challenges: (1) long lead times in the design phase, (2) quicker employee turnover in relation to long education time for newly employed personnel, and (3) automatic generation of digital information for manufacturing automation (Jensen et al. 2012; Khalili-Araghi and Kolarevic 2016; Monizza et al. 2018). Use of AR\&VR technologies are seen in both companies as means to improve the representation of products to customers and to enable more efficient manual assembly of special elements. However, the BIM development is a prerequisite for the successful use of these technologies.

Regarding the smart manufacturing support in knowledge platform asset, the companies want to digitalize explicit knowledge in form of parametric modelling tools to actively support the employees. This is in line with the work of Singh et al. (2015). This will result in the shift of 
knowledge into the process platform asset. On the other hand, there are several key people within the organization that have experience and know-how about problem solving that is hard to document. Another challenge with the knowledge asset is that sales personnel is often ignorant regarding the building system and therefore, promising the customer something outside the building system boundary, particularly when the market goes down. Both companies are facing challenges of outsourcing the engineering of installations to the consultancy firms. These firms use different softwares that is inoperable with the companies' CAD software. Therefore, the aim is to further improve the internal efficiency by utilizing the benefits of horizontal IT integration.

\section{CONCLUSIONS}

The theoretical and empirical findings regarding smart manufacturing support to product platforms in industrialized house building are presented and a match can be observed. These findings should be interpreted with circumspection as the study included data from two companies. The differences can indicate future work directions in order to expand the knowledge on the support of smart manufacturing to product platforms in IHB in both theory and practise: there is limited research in relation to flexible manufacturing automation support to component platform asset, BIM development and implementation of AR\&VR to support the process platform asset, and horizontal IT integration to support the relationship platform asset. On the other hand, there is a learning point for the companies. As shown by Isaac et al. (2016), component platform asset can be supported by automated component generation. It is important to note that one aspect covered by the literature from the context of manufacturing industries was not addressed neither theoretically nor empirically in the context of house building. This aspect is related to integrated design and manufacturing where digital information is exchanged in both directions (Mittal et al, 2017).

\section{ACKNOWLEDGEMENTS}

This research project is part of the graduate school ProWOOD which is a collaboration between School of Engineering at Jönköping University, Linnaeus University, Nässjö Träcentrum, several companies, and a research institute. The graduate school is financially supported by The Knowledge Foundation (KK-stiftelsen).

\section{REFERENCES}

Bonev, M., Wörösch, M., and Hvam, L. (2015). "Utilizing platforms in industrialized construction." Construction Innovation, 15(1), 84-106.

Dallasega, P., Rauch, E., and Linder, C. (2018). "Industry 4.0 as an enabler of proximity for construction supply chains: A systematic literature review." Computers in Industry, 99, 205-225.

Eid Mohamed, B., Elkaftangui, M., and Farouk, S. (2017). "A computer-based participatory model for customization in the UAE housing market." J. Enterp. Inf. Manage., 30(1), 1729.

Green, S. D., Fernie, S., and Weller, S. (2005). "Making sense of supply chain management: A comparative study of aerospace and construction." Constr. Manage. Econ., 23(6), 579-593. 
Halman, J. I. M., Hofer, A. P., and Van Vuuren, W. (2003). "Platform-Driven Development of Product Families: Linking Theory with Practice." Journal of Product Innovation Management, 20(2), 149-162.

Isaac, S., Bock, T., and Stoliar, Y. (2016). "A methodology for the optimal modularization of building design." Automation in construction, 65, 116-124.

Jansson, G. (2013). "Platforms in industrialised house-building." Luleå tekniska universitet.

Jensen, P., Olofsson, T., and Johnsson, H. (2012). "Configuration through the parameterization of building components." Automation in Construction, 23, 1-8.

Kang, H. S., Lee, J. Y., Choi, S., Kim, H., Park, J. H., Son, J. Y., Kim, B. H., and Do Noh, S. (2016). "Smart manufacturing: Past research, present findings, and future directions." International Journal of Precision Engineering and Manufacturing-Green Technology, 3(1), 111-128.

Karlsson, C. (2016). Research methods for operations management, Routledge.

Khalili-Araghi, S., and Kolarevic, B. (2016). "Development of a framework for dimensional customization system: A novel method for customer participation." Journal of Building Engineering, 5, 231-238.

Lessing, J., Stehn, L., and Ekholm, A. (2015). "Industrialised house-building - Development and conceptual orientation of the field." Constr. Innov., 15(3), 378-399.

Lidelöw, H., Stehn, L., Lessing, J., and Engström, D. (2015). Industriellt husbyggande, Studentlitteratur, Lund.

Malmgren, L., Jensen, P., and Olofsson, T. (2011). "Product modeling of configurable building systems - A case study." Electron. J. Inf. Technol. Constr., 16, 697-712.

Mittal, S., Khan, M. A., Romero, D., and Wuest, T. (2017). "Smart manufacturing: characteristics, technologies and enabling factors." Proceedings of the Institution of Mechanical Engineers, Part B: Journal of Engineering Manufacture, 0954405417736547.

Monizza, G. P., Bendetti, C., and Matt, D. T. (2018). "Parametric and Generative Design techniques in mass-production environments as effective enablers of Industry 4.0 approaches in the Building Industry." Automation in Construction, 92, 270-285.

Oesterreich, T. D., and Teuteberg, F. (2016). "Understanding the implications of digitisation and automation in the context of Industry 4.0: A triangulation approach and elements of a research agenda for the construction industry." Computers in Industry, 83, 121-139.

Persson, S., Malmgren, L., and Jonsson, H. (2009). "Information management in industrial housing design and manufacture." Journal Of Information Technology In Construction, 14, 110-122.

Robertson, D., and Ulrich, K. (1998). "Planning for product platforms." Sloan management review, 39(4), 19.

Rumsey, S. (2008). How to find information: a guide for researchers, McGraw-Hill Education (UK).

Said, H. M., Chalasani, T., and Logan, S. (2017). "Exterior prefabricated panelized walls platform optimization." Automation in Construction, 76, 1-13.

Singh, M. M., Sawhney, A., and Borrmann, A. "Modular Coordination and BIM: Development of Rule Based Smart Building Components." Elsevier Ltd, 519-527.

Styhre, A., and Gluch, P. (2010). "Managing knowledge in platforms: Boundary objects and stocks and flows of knowledge." Constr. Manage. Econ., 28(6), 589-599.

Thuesen, C., and Hvam, L. (2011). "Efficient on-site construction: learning points from a German platform for housing." Construction Innovation, 11(3), 338-355. 
Woodhead, R., Stephenson, P., and Morrey, D. (2018). "Digital construction: From point solutions to IoT ecosystem." Automation in Construction, 93, 35-46.

Yin, R. K. (1994). "Case study research: design and methods. 1994." Thousand Oaks, CA. 